\title{
Fluid intake, genetic variants of UDP-glucuronosyltransferases, and bladder cancer risk
}

\author{
$\mathrm{J} \mathrm{Wang}^{1}$, X Wu ${ }^{1}, \mathrm{~A} \mathrm{Kamat}{ }^{2}, \mathrm{H}$ Barton Grossman ${ }^{2}$, C P Dinney ${ }^{2}$ and J Lin ${ }^{*}, 1$ \\ ${ }^{1}$ Department of Epidemiology, Unit 1340, The University of Texas MD Anderson Cancer Center, 1155 Pressler Boulevard, Houston, \\ Texas 77030, USA and ${ }^{2}$ Department of Urology, The University of Texas MD Anderson Cancer Center, Houston, Texas 77030, USA
}

Background: Results of studies of fluid consumption and its association with bladder cancer have been inconsistent. Few studies have considered modification effects from genetic variants that may interact with the type of consumed fluids. UDPglucuronosyltransferases (UGTs), which are membrane-bound conjugating enzymes, catalyse the transformation of hydrophobic substrates to more water-soluble glucuronides to facilitate renal or biliary excretion. Whether genetic variants in UGTs could modulate the association between fluid intake and bladder cancer has not been studied.

Methods: We conducted a case-control study with 1007 patients with histopathologically confirmed bladder cancer and 1299 healthy matched controls. Fluid intake and epidemiologic data were collected via in-person interview. Multivariate unconditional logistic regression was used to estimate odds ratios (ORs) and the $95 \%$ confidence intervals $(95 \% \mathrm{Cl}$ ).

Results: After adjustment for potential confounders, high quantity of total fluid intake ( $\geqslant 2789 \mathrm{vs}<1696 \mathrm{ml}$ per day) conferred a $41 \%$ increased risk of bladder cancer $(O R=1.41 ; 95 \% \mathrm{Cl}=1.10-1.81)$. Specific fluids such as regular soft drinks and decaffeinated coffee were also associated with increased risks, whereas tea, wine, and liquor were associated with decreased risks. Among 83 single-nucleotide polymorphisms in the UGT gene family, 18 were significantly associated with bladder cancer risk. The most significant one was rs7571337, with the variant genotype conferring a $29 \%$ reduction in risk $(\mathrm{OR}=0.71 ; 95 \% \mathrm{Cl}=0.56-0.90)$.

Conclusions: Total and specific fluid intakes are associated with bladder cancer risk in the study population and that genetic variants of UGT genes could modulate the effects. These results facilitate identification of high-risk individuals and have important implications in bladder cancer prevention.

Bladder cancer is one of the most common genitourinary cancers in the United States, with an estimated 69250 new incident cases and 14990 deaths in 2011 (Siegel et al, 2011). Established risk factors of bladder cancer include male sex, old age, tobacco smoking, and occupational exposures to aromatic amines $(\mathrm{Wu}$ et al, 2008).

The role of fluid consumption and its association with the risk of bladder cancer has gained much attention in recent decades (Altieri et al, 2003; Ros et al, 2011). However, past findings have been inconsistent. For example, pooled data from six case-control studies indicated that total fluid intake was associated with an increased risk in men (Villanueva et al, 2006), whereas findings from a large case-control study in seven French hospitals did not support such an association (Geoffroy-Perez and Cordier, 2001). In a Health Professionals Follow-up Study, high fluid intake was associated with reduced risk of bladder cancer (Michaud et al, 1999). It has been hypothesised that a high fluid intake might dilute metabolites in the urine and increase the frequency of voiding, thus reducing contact of carcinogens with the bladder epithelium (Pelucchi et al, 2006). This hypothesis would suggest that higher levels of fluid intake are beneficial (Bruemmer et al, 1997). In contrast, given that fluids may contain substances 
carcinogenic to the bladder, an increase in total fluid quantity might increase the net flow of carcinogens into the bladder and thus increase the risk of cancer (Claude et al, 1986).

Potential carcinogenic substances found in specific fluids are metabolised by cytochrome $\mathrm{P} 450$ to generate reactive compounds, following a conjugation process by phase II enzymes to generate metabolites for further degradation so that the final product is highly water soluble and easily excreted in bile or urine (Lampe, 2007). Differences in metabolic enzyme activity may modulate the activation and degradation of consumed fluids, resulting in different carcinogenic effects. UDP-glucuronosyltransferases (UGTs), which are membrane-bound conjugating enzymes, catalyse the transformation of hydrophobic substrates to more water-soluble glucuronides to facilitate renal or biliary excretion (King et al, 2000; Guillemette, 2003). Target substrates for UGTs cover a wide range of compounds with divergent chemical structures, including dietary by-products, endogenous metabolites, drugs, and occupational and environmental pollutants (Lin et al, 2005). Genetic variants have been identified in coding and noncoding regions of UGTs, and the variant genotypes have been reported to be associated with bladder cancer risk (Desai et al, 2003; Rothman et al, 2010). It has been shown that constitutive expression of UGTs in the normal mucosa could protect organs from carcinogens released in the bladder (Giuliani et al, 2005). Tissue-specific loss or decreased expression of UGTs has been reported to be able to experimentally induce bladder tumours in animal models (Giuliani et al, 2001; Iida et al, 2010).

Considering the role of glucuronidation in the inactivation or elimination of endogenous and exogenous compounds through urine excretion, we hypothesised that genetic variants in UGTs could modulate the effects of fluid intake by interacting with the various types of fluid consumed. To test this hypothesis, we conducted a case-control study to investigate the main effects of total and specific fluid intakes on the risk of bladder cancer, and we further explored their joint effects with selected single-nucleotide polymorphisms (SNPs) of UGT genes.

\section{MATERIALS AND METHODS}

Study population. This study started patient recruitment in 1999 and is currently ongoing. The response rates for cases and controls were $92 \%$ and $77 \%$, respectively (Wu et al, 2007). Bladder cancer cases were enrolled from the University of Texas MD Anderson Cancer Center and Baylor College of Medicine. All patients had histologically confirmed bladder cancer with no prior treatment of chemotherapy or radiotherapy at the time of recruitment. The majority of cases had transitional cell carcinoma, but all histology types were included. There were no restrictions on recruitment regarding age, sex, race, or cancer stage. The control subjects were healthy individuals without cancer history (except non-melanoma skin cancer) and were recruited from the Kelsey-Seybold Clinic, the largest private multispecialty group practice in the Houston metropolitan area, with 18 clinics, more than 325 physicians, and more than 400000 patients. The control subjects were healthy individuals who visit the Kelsey-Seybold Clinics for annual health checkups. On the day of interview, they came to the clinics for the purpose of participating in this study but not for treating any diseases. Controls were frequency matched to the patients by age ( \pm 5 years), sex, and ethnicity. This study was approved by the Institutional Review Boards of MD Anderson Cancer Center, Kelsey-Seybold Clinic, and Baylor College of Medicine. Written informed consent was obtained from all study subjects. Individuals who never smoked or had smoked less than 100 cigarettes in his or her lifetime were defined as never smoker. Individuals who had quit smoking at least 1 year before diagnosis were defined as former smokers. Individuals who were currently smoking or who had stopped less than 1 year before diagnosis were defined as current smokers. Ever smoker include both former and current smoker. Pack year of smoking was defined as number of cigarettes per day divided by 20 (20 cigarettes per pack) and then multiplied by years of smoking.

Data collection. Trained MD Anderson Cancer Center staff interviewers administered a risk factor questionnaire to all participants. Data collected included demographic characteristics, occupation history, tobacco use history, medical history, lifestyle factors, and family history of cancer. In addition, a food frequency questionnaire (FFQ) was administered to assess usual food intake during the year before diagnosis for the cases and the year before the interview among controls. The FFQ was derived from the Health Habits and History Questionnaire (HHHQ) developed by the National Cancer Institute. The questionnaire included a semiquantitative food frequency list of food and beverage items, ethnic foods commonly consumed in the Houston area, an openended section, and dietary behaviours such as dining at restaurants and cooking methods. The validity and reliability of this questionnaire have been documented previously (Block et al, 1992). After informed consent was obtained, a blood sample was collected from each participant for molecular analyses.

Calculation of fluid intake. We calculated total and specific fluid intakes using the beverage items in the HHHQ. In the HHHQ, responses regarding the frequency of consumption and amount of consumption each time were recorded. Total fluid intake was expressed as milliliters per day. Specific fluid intake quantities were expressed in servings per day, based on the standard size of glasses or cups according to the particular fluid type. For example, one serving of coffee, tea, water, or total alcoholic beverage is equivalent to one cup ( $8 \mathrm{fl} \mathrm{oz} ; 240 \mathrm{ml}$ ); one serving of beer is equivalent to one glass or one bottle $(12 \mathrm{fl} \mathrm{oz;} 360 \mathrm{ml})$; one serving of wine is equivalent to one glass $(4 \mathrm{fl} \mathrm{oz} ; 120 \mathrm{ml}$ ); one serving of liquor is equivalent to one drink ( $4 \mathrm{fl} \mathrm{oz}$ ) or one shot $(45 \mathrm{ml})$. Water intake was calculated by adding up the consumption of both tap and bottled water.

Single-nucleotide polymorphism selection and genotyping. Owing to the small number of minority participants in the study populations, we restricted the analysis of SNPs to Caucasians (non-Hispanic whites) in this study. Tagging SNPs were identified from the HapMap database (http://www.hapmap.org) with the following selection criteria: $r^{2} \geqslant 0.8$, minor allele frequency $\geqslant 0.05$ in Caucasians, and within $10 \mathrm{~kb}$ upstream of the $5^{\prime}$ untranslated region (UTR) and $10 \mathrm{~kb}$ downstream of the $3^{\prime}$ UTR of the gene. In addition, we chosed potentially functional SNPs, including coding SNPs and SNPs in UTRs, promoters or splicing sites. Genotyping of selected SNPs followed the workflow of the Illumina Infinium II assay (Illumina, San Diego, CA, USA). A total of 83 SNPs in UGT genes were initially selected, and 8 SNPs were removed due to lowcall rate $(<90 \%)$, departure from Hardy-Weinberg equilibrium $(P<0.01)$, or minor allele frequency $<0.01$. Seventy-five SNPs were included in the final analysis (Supplementary Table 1).

Statistical analysis. Statistical analysis was performed by using STATA 10.0 software (StataCorp, College Station, TX, USA) and the R software (http://www.r-project.org/). All tests were two-sided with the significance level set at 0.05 . Distributions of characteristics between cases and controls were tested using the $\chi^{2}$ test (for categorical variables), Student's $t$-test (for continuous variables with normal distribution), or Kruskal-Wallis nonparametric test (for continuous variables without normal distribution) where appropriate. The multivariate unconditional logistic regression model was used to calculate odds ratios (ORs) and 95\% confidence intervals (95\% CIs), whereas adjusting for age, sex, ethnicity, energy intake, and smoking status. For total fluid and water 
intakes, ORs were calculated using quartile cutoff points in controls. For tea, soft drink, coffee, and alcoholic beverages, the consumption was first categorised into two groups (never drinkers and ever drinkers), and then the subgroup of ever drinkers was further categorised into low-intake and high-intake groups according to the median consumption in the control population. For the main effect of single SNP analysis, we tested three different genetic models: dominant model, recessive model, and additive model. The bestfitting model was the one with the smallest $P$-value among the three models. If the counts for the homozygous variant genotype were less than $5 \%$ in both cases and controls, only the dominant model that had the highest statistical power was considered. To control for false positives resulting from multiple comparisons, we adjusted the $P$-values of single SNP by using the $q$-value module in the $\mathrm{R}$ software. The analysis of SNPs was restricted to Caucasians only to address population stratification in genetic association studies. Interactions between variables were included in the multivariate logistic regression model as cross-product terms, and the significance was assessed using the likelihood ratio test.

\section{RESULTS}

As shown in Table 1, 1007 cases (784 men, 223 women) and 1299 controls (1013 men, 286 women) were included in the study. The majority of the study participants were white $(91.46 \%$ for cases and $90.84 \%$ for controls, $P=0.595)$. The distributions of sex, age, and ethnicity were comparable between cases and controls as a result of frequency matching. The proportion of current smokers was higher in cases than in controls $(24.93 \%$ vs $8.39 \%, P<0.001)$. Smokers in the case group also had higher number of pack-years of

\begin{tabular}{|c|c|c|c|}
\hline & Control $(n=1299)$ & Case $(n=1007)$ & \\
\hline Characteristic & $n(\%)$ & $n(\%)$ & $P$-value \\
\hline \multicolumn{4}{|l|}{ Sex } \\
\hline $\begin{array}{l}\text { Men } \\
\text { Women }\end{array}$ & $\begin{array}{r}1013(77.98) \\
286(22.02)\end{array}$ & $\begin{array}{l}784(77.86) \\
223(22.14)\end{array}$ & $0.941^{a}$ \\
\hline \multicolumn{4}{|l|}{ Age (years) } \\
\hline Mean \pm s.d. & $64.20 \pm 11.37$ & $64.64 \pm 11.12$ & $0.352^{b}$ \\
\hline \multicolumn{4}{|l|}{ Ethnicity } \\
\hline $\begin{array}{l}\text { White } \\
\text { Hispanic } \\
\text { Black } \\
\text { Other }\end{array}$ & $\begin{array}{c}1180(90.84) \\
49(3.77) \\
60(4.62) \\
10(0.77)\end{array}$ & $\begin{array}{c}921(91.46) \\
40(3.97) \\
36(3.57) \\
10(0.99)\end{array}$ & $0.595^{\mathrm{a}}$ \\
\hline \multicolumn{4}{|l|}{ Smoking status } \\
\hline $\begin{array}{l}\text { Never } \\
\text { Former } \\
\text { Current }\end{array}$ & $\begin{array}{l}594(45.73) \\
596(45.88) \\
109(8.39)\end{array}$ & $\begin{array}{l}287(28.50) \\
469(46.57) \\
251(24.93)\end{array}$ & $<0.001^{\mathrm{a}}$ \\
\hline \multicolumn{4}{|c|}{ Smoking pack-years } \\
\hline Median (range) & $22.5(0.05-165)$ & $36.0(0.10-176)$ & $<0.001^{\mathrm{c}}$ \\
\hline \multicolumn{4}{|c|}{ Energy intake (kcal per day) } \\
\hline Median (range) & $1968(516-9502)$ & $2258(381-6988)$ & $<0.001^{c}$ \\
\hline $\begin{array}{l}\mathbf{a}_{\chi^{2}} \text { test. } \\
\mathbf{b}_{\text {Student's t-test. }} \\
{ }^{c_{\text {Kruskal-Wallis test. }}}\end{array}$ & & & \\
\hline
\end{tabular}

smoking than smokers in the control group (median: 36.0 vs 22.5, $P<0.001)$. Energy intake was significantly higher in cases than in controls (2258 vs $1968 \mathrm{kcal}$ per day, $P<0.001$; Table 1).

The median total fluid intake was higher in cases than in controls (2423 vs $2215 \mathrm{ml}$ per day, $P<0.001$ ). For water, tea, soft drinks, coffee, and total alcoholic beverages, the median (95\% CI) servings per day were $3.50,0.68,0.71,2.00$, and 0.55 among cases and $3.50,0.71,0.71,2.00$, and 0.39 among controls, respectively (Supplementary Table 2).

After adjustment for potential confounders, the highest quartile of fluid intake $(\geqslant 2789 \mathrm{ml}$ per day) was associated with an increased risk of bladder cancer, with an OR of 1.41 (95\% $\mathrm{CI}=1.10-1.81)$, compared with the lowest quartile $(<1696 \mathrm{ml}$ per day; Table 2). No significant association was found between overall water consumption (tap and bottle water combined) and the risk of bladder cancer. Increased tea consumption conferred significantly reduced risks, with ORs of $0.74(95 \% \mathrm{CI}=0.59-0.92)$ for $<0.71$ serving per day and $0.65(95 \% \mathrm{CI}=0.53-0.81)$ for $\geqslant 0.71$ serving per day, with a significant dose-response trend $(P$ for trend $<0.001)$. When stratified by type of tea, the protective effects were observed for black, green, and herbal teas but not for decaffeinated tea consumption. For soft drink consumption, compared with never drinkers, low ( $<0.70$ serving per day) and high $(\geqslant 0.71$ serving per day) consumption of soft drinks conferred $26 \%(\mathrm{OR}=1.26,95 \% \mathrm{CI}=1.00-1.60)$ and $34 \%(\mathrm{OR}=1.34,95 \%$ $\mathrm{CI}=1.05-1.70)$ increased risks of bladder cancer. However, these increased risks were observed only with regular soft drink consumption and not with diet soft drink consumption. Overall, coffee consumption was not significantly associated with bladder cancer risk. However, an increased risk was found for consuming decaffeinated coffee, with ORs of $1.75(95 \% \mathrm{CI}=1.28-2.41)$ for $<1$ serving per day and $1.37(95 \% \mathrm{CI}=1.09-1.73)$ for $\geqslant 1$ serving per day $(P$ for trend $=0.001)$. This increased risk was not observed in regular coffee drinkers. Consumption of alcoholic beverages was inversely associated with bladder cancer risk, with ORs 0.59 (95\% $\mathrm{CI}=0.48-0.74)$ for $<0.39$ serving per day and $0.77 \quad(95 \%$ $\mathrm{CI}=0.62-0.95)$ for $\geqslant 0.39$ serving per day. The inverse association was observed only in wine and liquor drinkers and not in beer drinkers. For example, compared with never drinkers, wine consumption ( $\geqslant 0.14$ serving/day) conferred $41 \%$ reduction in bladder cancer risk $(\mathrm{OR}=0.59,95 \% \mathrm{CI}=0.48-0.73)$.

To explore potential association between smoking and beverage choice, we performed an analysis of smoking status and beverage drinking habits in controls. Results showed that there was significant difference in total and some specific fluid intake by smoking status (Supplementary Table 3). Specifically, smokers tended to have high consumption of total fluid, coffee of all types, regular coffee, total alcoholic beverages, beer, and liquor. In contrast, never smokers were more likely to have high consumption of tea, especially green tea and other herbal tea.

We further performed a stratified analysis by smoking status. Results showed that the inverse association between bladder cancer and all types of tea and specific tea, all types of alcoholic beverages, and liquor was only significant in ever smokers (Supplementary Table 4). Similarly, the increased risk associated with all types of soft drinks and regular soft drinks was significant in ever smokers but not in never smokers (Supplementary Table 4). However, there was no significant interaction between smoking and fluid intake of any kind.

A total of 1501 subjects ( 718 cases, 783 controls) with genotype data available were included in the SNP analysis. We did an analysis comparing demographic and fluid intake differences between all subjects and subjects with genotype data available but found no differences (data not shown). Eighteen SNPs in the UGT gene family were individually associated with bladder cancer (Table 3). Of these 18 SNPs, 16 are located in the genes of the UGT1 family and 2 in the genes of the UGT2 family. After 


\begin{tabular}{|c|c|c|c|}
\hline Fluid intake & Control/case & OR $(95 \% \mathrm{Cl})^{\mathrm{a}}$ & $\mathbf{P}$ \\
\hline \multicolumn{4}{|c|}{ Total fluid intake (ml/day) } \\
\hline $\begin{array}{l}<1696 \\
1696-2215 \\
2215-2789 \\
\geq 2789 \\
\mathrm{P} \text { for trend }\end{array}$ & $\begin{array}{l}324 / 218 \\
325 / 215 \\
324 / 191 \\
325 / 382\end{array}$ & $\begin{array}{c}1 \\
0.92(0.71-1.18) \\
0.81(0.62-1.05) \\
1.41(1.10-1.81)\end{array}$ & $\begin{array}{c}0.517 \\
0.109 \\
0.007 \\
0.01\end{array}$ \\
\hline \multicolumn{4}{|c|}{ Water (serving/day) } \\
\hline $\begin{array}{l}<2 \\
2-3.4 \\
3.5-4.9 \\
\geq 5 \\
\text { P for trend }\end{array}$ & $\begin{array}{l}217 / 202 \\
300 / 217 \\
329 / 204 \\
452 / 383\end{array}$ & $\begin{array}{c}1 \\
0.84(0.64-1.11) \\
0.78(0.60-1.03) \\
1.02(0.80-1.31)\end{array}$ & $\begin{array}{l}0.218 \\
0.078 \\
0.856 \\
0.565\end{array}$ \\
\hline \multicolumn{4}{|c|}{ All types of tea (serving/day) } \\
\hline $\begin{array}{l}\text { Never } \\
0.1-0.70 \\
0.71+ \\
P \text { for trend }\end{array}$ & $\begin{array}{l}312 / 328 \\
472 / 342 \\
515 / 337\end{array}$ & $\begin{array}{c}1 \\
0.74(0.59-0.92) \\
0.65(0.53-0.81)\end{array}$ & $\begin{array}{l}0.007 \\
<0.001 \\
<0.001\end{array}$ \\
\hline \multicolumn{4}{|c|}{ Decaffeinated tea (serving/day) } \\
\hline $\begin{array}{l}\text { Never } \\
0.1-0.56 \\
0.57+ \\
P \text { for trend }\end{array}$ & $\begin{array}{c}1155 / 877 \\
66 / 61 \\
78 / 69\end{array}$ & $\begin{array}{c}1 \\
1.38(0.95-2.00) \\
1.35(0.96-1.92)\end{array}$ & $\begin{array}{l}0.092 \\
0.088 \\
0.031\end{array}$ \\
\hline \multicolumn{4}{|c|}{ Black tea (serving/day) } \\
\hline $\begin{array}{l}\text { Never } \\
0.1-0.56 \\
0.57+ \\
P \text { for trend }\end{array}$ & $\begin{array}{l}515 / 492 \\
381 / 250 \\
403 / 265\end{array}$ & $\begin{array}{c}1 \\
0.71(0.57-0.88) \\
0.67(0.54-0.83)\end{array}$ & $\begin{array}{l}0.001 \\
<0.001 \\
<0.001\end{array}$ \\
\hline \multicolumn{4}{|c|}{ Green tea (serving/day) } \\
\hline $\begin{array}{l}\text { Never } \\
0.1-0.13 \\
0.14+ \\
P \text { for trend }\end{array}$ & $\begin{array}{l}972 / 828 \\
133 / 88 \\
194 / 91\end{array}$ & $\begin{array}{c}1 \\
0.82(0.61-1.11) \\
0.60(0.45-0.79)\end{array}$ & $\begin{array}{c}0.197 \\
<0.001 \\
<0.001\end{array}$ \\
\hline \multicolumn{4}{|c|}{ Other herbal tea (serving/day) } \\
\hline $\begin{array}{l}\text { Never } \\
0.1-0.13 \\
0.14+ \\
P \text { for trend }\end{array}$ & $\begin{array}{c}1120 / 937 \\
82 / 26 \\
97 / 44\end{array}$ & $\begin{array}{c}1 \\
0.44(0.27-0.69) \\
0.60(0.41-0.88)\end{array}$ & $\begin{array}{c}<0.001 \\
0.009 \\
<0.001\end{array}$ \\
\hline \multicolumn{4}{|c|}{ All types of soft drink (serving/day) } \\
\hline $\begin{array}{l}\text { Never } \\
0.1-0.70 \\
0.71+ \\
P \text { for trend }\end{array}$ & $\begin{array}{l}286 / 187 \\
506 / 393 \\
507 / 427\end{array}$ & $\begin{array}{c}1 \\
1.26(1.00-1.60) \\
1.34(1.05-1.70)\end{array}$ & $\begin{array}{l}0.055 \\
0.018 \\
0.025\end{array}$ \\
\hline \multicolumn{4}{|c|}{ Diet soft drink (serving/day) } \\
\hline $\begin{array}{l}\text { Never } \\
0.1-0.85 \\
0.86+ \\
P \text { for trend }\end{array}$ & $\begin{array}{l}705 / 589 \\
294 / 197 \\
300 / 221\end{array}$ & $\begin{array}{c}1 \\
0.96(0.77-1.19) \\
1.06(0.85-1.32)\end{array}$ & $\begin{array}{c}0.702 \\
0.62 \\
0.713\end{array}$ \\
\hline \multicolumn{4}{|c|}{ Regular soft drink (serving/day) } \\
\hline $\begin{array}{l}\text { Never } \\
0.1-0.34 \\
0.35+ \\
P \text { for trend }\end{array}$ & $\begin{array}{l}758 / 505 \\
270 / 232 \\
271 / 270\end{array}$ & $\begin{array}{c}1 \\
1.28(1.03-1.60) \\
1.27(1.02-1.58)\end{array}$ & $\begin{array}{l}0.025 \\
0.032 \\
0.014\end{array}$ \\
\hline
\end{tabular}

Table 2. (Continued)

\begin{tabular}{|l|l|l|l}
\hline Fluid intake & Control/case & OR $(95 \% \mathrm{Cl})^{\mathrm{a}}$ & $\mathrm{P}$ \\
\hline
\end{tabular}

All types of coffee (serving/day)

\begin{tabular}{|l|c|c|c|}
\hline Never & $259 / 155$ & 1 & \\
$0.1-1.9$ & $375 / 271$ & $1.13(0.87-1.47)$ & 0.372 \\
$2+$ & $665 / 581$ & $1.14(0.90-1.46)$ & 0.283 \\
P for trend & & & 0.336
\end{tabular}

Decaffeinated coffee (serving/day)

\begin{tabular}{l|c|c|c} 
Never & $1006 / 717$ & 1 & \\
$0.1-0.9$ & $89 / 94$ & $1.75(1.28-2.41)$ & 0.001 \\
$1+$ & $203 / 196$ & $1.37(1.09-1.73)$ & 0.007 \\
$P$ for trend & & & 0.001 \\
\hline
\end{tabular}

Regular coffee (serving/day)

\begin{tabular}{l|c|c|c} 
Never & $389 / 288$ & 1 & \\
$0.1-1.9$ & $332 / 235$ & $0.91(0.72-1.15)$ & 0.437 \\
$2+$ & $577 / 484$ & $0.92(0.74-1.13)$ & 0.401 \\
P for trend & & & 0.426 \\
\hline
\end{tabular}

Total alcoholic beverage (serving/day)

\begin{tabular}{|l|c|c|c|}
\hline Never & $368 / 366$ & 1 & \\
$0.1-0.38$ & $465 / 265$ & $0.59(0.48-0.74)$ & $<0.001$ \\
$0.39+$ & $466 / 376$ & $0.77(0.62-0.95)$ & 0.016 \\
P for trend & & & 0.021 \\
\hline
\end{tabular}

Wine (serving/day)
\begin{tabular}{l|c|c|c|} 
Never & $574 / 586$ & 1 & \\
$0.1-0.13$ & $329 / 205$ & $0.66(0.53-0.82)$ & $<0.001$ \\
$0.14+$ & $396 / 216$ & $0.59(0.48-0.73)$ & $<0.001$ \\
P for trend & & & $<0.001$ \\
\hline
\end{tabular}

Beer (serving/day)
\begin{tabular}{l|c|c|c} 
Never & $727 / 563$ & 1 & \\
$0.1-0.13$ & $256 / 183$ & $0.96(0.76-1.21)$ & 0.749 \\
$0.14+$ & $316 / 261$ & $0.99(0.80-1.24)$ & 0.961 \\
P for trend & & & 0.917 \\
\hline
\end{tabular}

\begin{tabular}{|l|c|c|c|}
\hline \multicolumn{4}{|l|}{ Liquor (serving/day) } \\
\hline Never & $748 / 651$ & 1 & \\
$0.1-0.06$ & $274 / 149$ & $0.66(0.52-0.83)$ & $<0.001$ \\
$0.07+$ & $277 / 207$ & $0.77(0.61-0.96)$ & 0.019 \\
P for trend & & & 0.003 \\
\hline
\end{tabular}

Abbreviations: $\mathrm{Cl}=$ confidence interval; $\mathrm{OR}=$ odds ratio.

adjusting for age, sex, ethnicity, energy intake, and smoking.

adjustment for multiple comparisons, 11 SNPs remained significant $(q<0.05)$, with the most significant one being rs7571337, which conferred $29 \%$ reduced risks for variant genotype carriers $(\mathrm{OR}=0.71,95 \% \mathrm{CI}=0.56-0.90)$.

We next stratified the association between total and specific fluid intakes by rs7571337 genotypes. As shown in Table 4, the increased risks conferred by total fluid intake $(\mathrm{OR}=2.02$ for total fluid intake $>=2789 \mathrm{ml}$ per day) and soft drink (OR $=2.01$ for soft drinks $0.1-1.9$ serving per day; $\mathrm{OR}=1.86$ for soft drinks 0.71 or more servings per day) and coffee consumption $(\mathrm{OR}=2.04$ for $0.1-1.9$ servings per day; $\mathrm{OR}=2.26$ for 2 or more servings per day) were significant only among rs7571337 AA genotype carriers, whereas the inverse association of tea $(\mathrm{OR}=0.56$ for $0.1-0.7$ servings per day; $\mathrm{OR}=0.62$ for 0.71 or more servings per day) and alcoholic beverage consumption ( $\mathrm{OR}=0.72$ for $0.1-0.38$ servings per day) was observed only in AG/GG carriers. 


\section{DISCUSSION}

This is the first study evaluating fluid consumption and its joint effects with genetic variants in UGT family genes. Our results suggest that total fluid intake was associated with an increased risk and that when stratified by specific fluid type, high intake of regular soft drinks increased the risk, whereas high intakes of regular tea, wine, and liquor decreased the risk. Moreover, we found the effects of fluid intake could be modified by genetic polymorphisms of UGT genes.

Previous epidemiological studies have evaluated the risks of bladder cancer in association to the fluid intake. A study in western New York reported that total fluid consumption was a risk factor for bladder cancer when a number of potential confounding risk factors were controlled for $(\mathrm{OR}=3.74 ; 95 \% \mathrm{CI}=2.55-5.47)$ the highest quartile of fluid consumption (Vena et al, 1993). It is hypothesised that moderate fluid intake might dilute metabolites in the urine and increase the frequency of voiding, thus reducing contact of carcinogens with the bladder epithelium (Bruemmer et al, 1997; Pelucchi et al, 2006). However, given that fluids may contain substances carcinogenic to the bladder, an increase in total fluid quantity might increase the net flow of carcinogens into the bladder and thus increase the risk of cancer (Claude et al, 1986). Our results are consistent with this hypothesis. However, total fluid consumption has been associated with a decreased risk in some studies (Michaud et al, 1999, 2007) or with no association in others (Geoffroy-Perez and Cordier, 2001; Brinkman and Zeegers, 2008; Jiang et al, 2008; Ros et al, 2011). The inconsistent results might be due to the lack of consideration of specific types of fluid. Also, studies varied in size and the calculation of fluid intake also varied by studies, which makes comparison between studies difficult. Moreover, previous studies did not consider genetic variations and differences in host metabolic enzyme activity could also partly be responsible for the inconsistent results.

UGTs are the major class of metabolic enzymes that catalyse phase II reactions (Iyanagi, 2007). Other genes that are involved in the detoxification of carcinogens include glutathione $S$-transferases, sulfotransferase and $N$-acetyltransferase. Potential chemical existing in the beverages first get activated by phase I drug metabolising enzymes, and then be deactivated by phase II drug metabolising enzymes like UGTs. A full picture of the lipophilic process of the chemicals in the various fluids should be discussed in the context of both phase I and phase II metabolic phases. In the liver and gastrointestinal tract, UGTs are predominantly expressed, but the expression of human UGTs varies widely between individuals (Mackenzie et al, 2005). Mediated by the UGTs of the endoplasmic reticulum and nuclear envelope, a myriad of lipophilic chemicals are rendered water soluble, and this process has a critical role in the detoxification of exogenous and endogenous compounds (Iyanagi, 2007). In light of the association of genetic predisposition and fluid intake to cancer risk, we stratified the analysis of total and specific fluid intakes by genetic variants in the UGTs to further elucidate their joint effects. Our findings supported the hypothesis that effects of fluid intake could be modified by genetic polymorphisms of UGT genes individually and cumulatively. However, the functions of the significant SNPs that we found in this study were unclear. More in-depth molecular studies are needed to confirm the functional significance of the SNPs. The most significant SNP, rs7571337, is located in the intron region of UGT1A8 (UDP glucuronosyltransferase 1 family, polypeptide A8). Whether this SNP can alter the expression of the UGT1A8 gene or links to other functional loci needs to be verified.

In addition to total fluid intake, we also evaluated specific fluid items, including water, tea, soft drinks, coffee, and alcoholic beverages. A Health Professionals Follow-up Study reported that the consumption of water contributed to a lower risk (relative risk, 0.49 (95\% CI: $0.28-0.86)$ for $\geqslant 1440$ vs $<240 \mathrm{ml}$ per day; Michaud et al, 1999). A case-control study of bladder cancer in Spain also found a significant inverse association for water intake $(\mathrm{OR}=0.47$; $95 \% \mathrm{CI}=0.33-0.66$; for $>1399$ vs $<400 \mathrm{ml}$ per day; Michaud et al, 2007). Inconsistent with these former findings (Michaud et al, 1999, 2007), we found no significant association between overall water consumption and bladder cancer. This inconsistency in findings may be due to differences in exposures to disinfection byproducts and other water contaminants that can vary substantially by study population (Michaud et al, 2007). Drinking tap water containing chlorine and chlorination by-products has been demonstrated to increase the risk of developing bladder cancer in several studies (Cantor et al, 1987; Villanueva et al, 2004). Unfortunately, our study did not collect information on the source of drinking water, so we were not able to compare the effects of drinking tap $v s$ non-tap water on bladder cancer risk.

Our results suggest a protective effect for tea drinking. Tea is one of the most common beverages consumed worldwide (Boehm et al, 2009). It contains several polyphenolic components with antioxidant properties. Extracts of tea have been shown to inhibit the formation and development of tumours in animal models (Yang et al, 2009). Considerable evidence from epidemiological studies has indicated the potential use of tea for cancer prevention (Bushman, 1998; Boehm et al, 2009; Yang et al, 2009).

Our results also suggested that high consumption of soft drinks was associated with increased risk, and this association was found for drinkers of regular soft drinks but not drinkers of diet soft drinks. Ingestion of soft drinks tends to cause a rapid increase in blood sugar and insulin relative to many other beverages and foods (Odegaard et al, 2010). Soft drinks and other sweetened beverages may contribute to the risk of obesity and diabetes (Albanes, 1987; Mueller et al, 2010; Odegaard et al, 2010). However, the consumption of added sugar or of sugar-sweetened foods and beverages in the risk of human cancers is still controversial. We recently reported high caloric intake was associated with bladder cancer (Lin et al, 2010).

The role of coffee in bladder cancer has been examined in several epidemiological studies, with some conflicting results (Pelucchi et al, 2008; Pelucchi and La Vecchia, 2009). A study by a Spanish group reported no significant association between coffee consumption and bladder cancer (Villanueva et al, 2009). A prospective cohort study in Japan found that coffee was positively associated with bladder cancer risk in men, but without statistical significance (Kurahashi et al, 2009). However, results from the Netherlands Cohort Study suggested a probable inverse association between coffee consumption and bladder cancer risk in women (Zeegers et al, 2001). Our results are consistent with previously published epidemiological studies that suggest a null or slightly positive association between coffee and bladder cancer. Coffee is a complex mixture of chemicals, and a large array of compounds found in coffee could potentially alter cancer risk through several biological mechanisms (Higdon and Frei, 2006; Nkondjock, 2009). Animal studies have shown the effect of caffeine to both stimulate and suppress tumours, depending upon the species and the phase of administration (Nkondjock, 2009). In this study, an increased risk for bladder cancer was found only for decaffeinated coffee rather than regular coffee. Whether this difference can be attributed to the role of caffeine or other chemicals in these two types of coffee needs further study. In addition, a potential misclassification of coffee types may be another explanation. For example, former users of caffeinated coffee among the cases may have switched to decaffeinated coffee as part of a healthy lifestyle, resulting in the overestimation of risk.

Findings from our study were consistent with former reports that alcoholic beverage consumption was inversely related to bladder cancer risk (Jiang et al, 2007). This protective effect was 
Table 3. Association between genetic polymorphisms of UGTs and bladder cancer risk

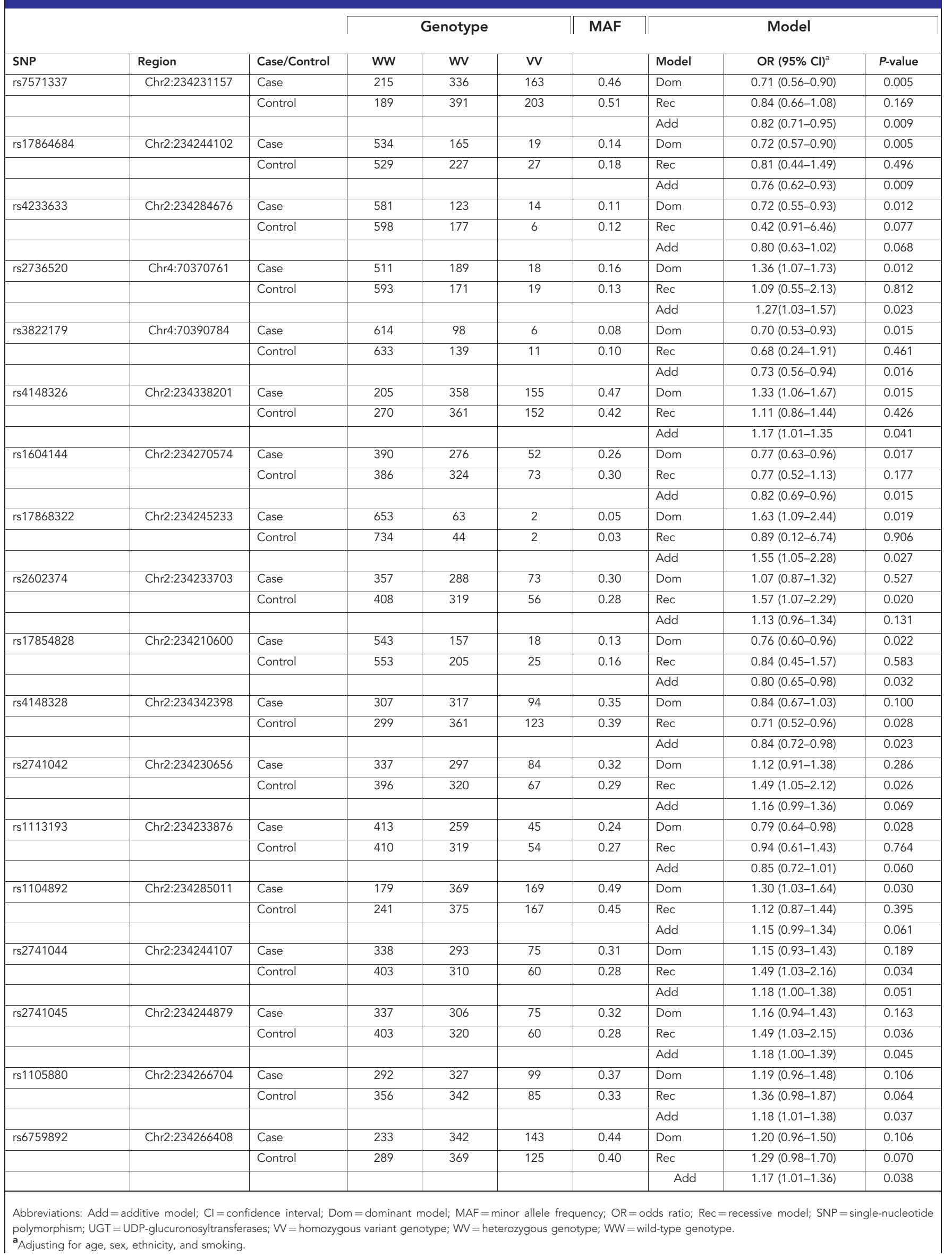


Table 4. Association between fluid intake and the risk of bladder cancer stratified by rs7571337 genotype

\begin{tabular}{|c|c|c|c|c|c|c|c|c|}
\hline \multirow[b]{2}{*}{ Variable } & \multicolumn{4}{|c|}{ AA } & \multicolumn{4}{|c|}{$\mathbf{A G}+\mathbf{G G}$} \\
\hline & Control & Case & OR $(95 \% \mathrm{Cl})^{a}$ & $P$-value & Control & Case & OR $(95 \% \mathrm{Cl})^{a}$ & $P$-value \\
\hline \multicolumn{9}{|c|}{ Total fluid intake ( $\mathrm{ml}$ per day) } \\
\hline $\begin{array}{l}<1696 \\
1696-2215 \\
2215-2789 \\
\geqslant 2789 \\
P \text { for trend }\end{array}$ & $\begin{array}{l}40 \\
52 \\
53 \\
44\end{array}$ & $\begin{array}{l}37 \\
51 \\
36 \\
91\end{array}$ & $\begin{array}{c}1 \\
0.98(0.53-1.81) \\
0.73(0.39-1.37) \\
2.02(1.08-3.78)\end{array}$ & $\begin{array}{l}0.955 \\
0.329 \\
0.028 \\
0.039\end{array}$ & $\begin{array}{l}126 \\
143 \\
150 \\
175\end{array}$ & $\begin{array}{l}102 \\
102 \\
116 \\
179\end{array}$ & \begin{tabular}{|c|}
1 \\
$0.84(0.57-1.22)$ \\
$0.84(0.58-1.22)$ \\
$1.03(0.71-1.48)$
\end{tabular} & $\begin{array}{l}0.358 \\
0.368 \\
0.893 \\
0.776\end{array}$ \\
\hline \multicolumn{9}{|c|}{ Water (serving per day) } \\
\hline $\begin{array}{l}<2 \\
2-3.4 \\
3.5-4.9 \\
\geq 5 \\
P \text { for trend }\end{array}$ & $\begin{array}{l}31 \\
45 \\
43 \\
70\end{array}$ & $\begin{array}{l}48 \\
41 \\
40 \\
86\end{array}$ & $\begin{array}{c}1 \\
0.56(0.30-1.08) \\
0.62(0.32-1.19) \\
0.80(0.45-1.42)\end{array}$ & $\begin{array}{l}0.083 \\
0.149 \\
0.438 \\
0.814\end{array}$ & $\begin{array}{l}105 \\
139 \\
139 \\
211\end{array}$ & $\begin{array}{l}103 \\
119 \\
102 \\
175\end{array}$ & $\begin{array}{c}1 \\
0.99(0.67-1.46) \\
0.89(0.60-1.32) \\
0.96(0.67-1.37)\end{array}$ & $\begin{array}{l}0.971 \\
0.547 \\
0.809 \\
0.73\end{array}$ \\
\hline \multicolumn{9}{|c|}{ Tea (serving per day) } \\
\hline $\begin{array}{l}\text { Never } \\
0.1-0.70 \\
0.71+ \\
P \text { for trend }\end{array}$ & $\begin{array}{l}47 \\
81 \\
61\end{array}$ & $\begin{array}{l}59 \\
82 \\
74\end{array}$ & $\begin{array}{c}1 \\
0.89(0.53-1.49) \\
1.00(0.59-1.71)\end{array}$ & $\begin{array}{l}0.666 \\
0.999 \\
0.960\end{array}$ & $\begin{array}{l}135 \\
230 \\
229\end{array}$ & $\begin{array}{l}174 \\
161 \\
164\end{array}$ & \begin{tabular}{|c|}
1 \\
$0.56(0.41-0.77)$ \\
$0.62(0.45-0.84)$
\end{tabular} & $\begin{array}{c}<0.001 \\
0.003 \\
0.004\end{array}$ \\
\hline \multicolumn{9}{|c|}{ Soft drinks (serving per day) } \\
\hline $\begin{array}{l}\text { Never } \\
0.1-0.70 \\
0.71+ \\
P \text { for trend }\end{array}$ & $\begin{array}{l}44 \\
68 \\
77\end{array}$ & $\begin{array}{l}30 \\
95 \\
90\end{array}$ & $\begin{array}{c}1 \\
2.01(1.13-3.59) \\
1.86(1.03-3.36)\end{array}$ & $\begin{array}{l}0.018 \\
0.039 \\
0.081\end{array}$ & $\begin{array}{l}113 \\
230 \\
251\end{array}$ & $\begin{array}{l}108 \\
184 \\
207\end{array}$ & \begin{tabular}{|c|}
1 \\
$0.86(0.61-1.22)$ \\
$0.88(0.62-1.24)$
\end{tabular} & $\begin{array}{l}0.403 \\
0.452 \\
0.517\end{array}$ \\
\hline \multicolumn{9}{|c|}{ Coffee (serving per day) } \\
\hline $\begin{array}{l}\text { Never } \\
0.1-1.9 \\
2+ \\
P \text { for trend }\end{array}$ & $\begin{array}{l}43 \\
52 \\
94\end{array}$ & $\begin{array}{r}24 \\
57 \\
134\end{array}$ & $\begin{array}{c}1 \\
2.04(1.07-3.89) \\
2.26(1.26-4.07)\end{array}$ & $\begin{array}{l}0.030 \\
0.007 \\
0.013\end{array}$ & $\begin{array}{l}106 \\
165 \\
323\end{array}$ & $\begin{array}{r}73 \\
127 \\
299\end{array}$ & \begin{tabular}{|c|}
1 \\
$1.08(0.72-1.60)$ \\
$1.06(0.74-1.52)$
\end{tabular} & $\begin{array}{l}0.716 \\
0.737 \\
0.796\end{array}$ \\
\hline \multicolumn{9}{|c|}{ Total alcoholic beverages (serving per day) } \\
\hline $\begin{array}{l}\text { Never } \\
0.1-0.38 \\
0.39+ \\
P \text { for trend }\end{array}$ & $\begin{array}{l}52 \\
63 \\
74\end{array}$ & $\begin{array}{l}72 \\
55 \\
88\end{array}$ & $\begin{array}{c}1 \\
0.64(0.38-1.09) \\
0.82(0.50-1.36)\end{array}$ & $\begin{array}{l}0.099 \\
0.448 \\
0.514\end{array}$ & $\begin{array}{l}176 \\
200 \\
218\end{array}$ & $\begin{array}{l}173 \\
136 \\
190\end{array}$ & \begin{tabular}{|c|}
1 \\
$0.72(0.53-1.00)$ \\
$0.89(0.65-1.21)$
\end{tabular} & $\begin{array}{l}0.048 \\
0.448 \\
0.490\end{array}$ \\
\hline
\end{tabular}

observed in both wine and liquor drinkers, but not for beer consumers. Wine is a moderately alcoholic drink made by fermentation of juice extracted from grapes. Wine contains antioxidant phenolic substances, including piceatannol. Experimental studies showed that piceatannol inhibited the proliferation of human bladder cancer cells by blocking cell cycle progression in the G0/G1 phase and inducing apoptosis, resulting in potential anti-carcinogenesis effects (Kuo and Hsu, 2008). In addition to wine, liquor also showed a protective effect in our study, which might be attributed to the role of alcohol. Previous reports documented the diuretic properties of alcohol in both experimental animals and humans, with alcohol consumption increasing urine flow, which may have a role in alcohol-mediated bladder cancer protection by decreasing the time that the bladder is exposed to carcinogens in the urine (Jiang et al, 2007).

In this study, cases and controls were retrospectively interviewed about their fluid consumption. Bias could potentially be introduced if the cases changed their diet habits before diagnosis due to the disease. To reduce this bias, cases were asked about their usual fluid intake a year before diagnosis. However, given that carcinogenesis is a long-term process, consumption of fluid one year before cancer diagnosis may not serve as an ideal measure of cumulative exposure. Further, it may be challenging to quantify fluid intake. Although there are better methods to quantify fluid intake than FFQ, in epidemiologic studies with large number of participants, FFQ is regarded as an efficient method to quantify the relative amount of intake, which determines the relative risk groups. Finally, although we adjusted for potential confounders such as age, sex, ethnicity, energy intake, and smoking in this study, we cannot exclude the possibility that some unmeasured confounders accounted for the associations found in this study.

In conclusion, results from the present study suggest that total fluid intake is associated with an increased risk of bladder cancer. Drinking tea, wine, and liquor confers decreased risks for bladder cancer, whereas regular soft drinks and decaffeinated coffee consumption may be possible risk factors. Results from this study 
suggest that genetic variants of UGT genes modulate an individual's susceptibility by interacting with the specific type of consumed fluids.

\section{ACKNOWLEDGEMENTS}

Supported by National Cancer Institute grants K07 CA134831 (J. Lin) and R01 CA74880 (X. Wu)

\section{CONFLICT OF INTEREST}

The authors declare no conflict of interests.

\section{REFERENCES}

Albanes D (1987) Caloric intake, body weight, and cancer: a review. Nutr Cancer 9(4): 199-217.

Altieri A, La Vecchia C, Negri E (2003) Fluid intake and risk of bladder and other cancers. Eur J Clin Nutr 57(Suppl 2): S59-S68.

Block G, Thompson FE, Hartman AM, Larkin FA, Guire KE (1992) Comparison of two dietary questionnaires validated against multiple dietary records collected during a 1-year period. J Am Diet Assoc 92(6): 686-693.

Boehm K, Borrelli F, Ernst E, Habacher G, Hung SK, Milazzo S, Horneber M (2009) Green tea (Camellia sinensis) for the prevention of cancer. Cochrane Database Syst Rev 8(3): CD005004.

Brinkman M, Zeegers MP (2008) Nutrition, total fluid and bladder cancer. Scand J Urol Nephrol Suppl 218: 25-36.

Bruemmer B, White E, Vaughan TL, Cheney CL (1997) Fluid intake and the incidence of bladder cancer among middle-aged men and women in a three-county area of western Washington. Nutr Cancer 29(2): 163-168.

Bushman JL (1998) Green tea and cancer in humans: a review of the literature. Nutr Cancer 31(3): 151-159.

Cantor KP, Hoover R, Hartge P, Mason TJ, Silverman DT, Altman R, Austin DF, Child MA, Key CR, Marrett LD (1987) Bladder cancer, drinking water source, and tap water consumption: a case-control study. J Natl Cancer Inst 79(6): 1269-1279.

Claude J, Kunze E, Frentzel-Beyme R, Paczkowski K, Schneider J, Schubert H (1986) Life-style and occupational risk factors in cancer of the lower urinary tract. Am J Epidemiol 124(4): 578-589.

Desai AA, Innocenti F, Ratain MJ (2003) UGT pharmacogenomics: implications for cancer risk and cancer therapeutics. Pharmacogenetics 13(8): 517-523.

Geoffroy-Perez B, Cordier S (2001) Fluid consumption and the risk of bladder cancer: results of a multicenter case-control study. Int J Cancer 93(6): 880-887.

Giuliani L, Ciotti M, Stoppacciaro A, Pasquini A, Silvestri I, De Matteis A, Frati L, Agliano AM (2005) UDP-glucuronosyltransferases 1A expression in human urinary bladder and colon cancer by immunohistochemistry. Oncol Rep 13(2): 185-191.

Giuliani L, Gazzaniga P, Caporuscio F, Ciotti M, Frati L, Agliano AM (2001) Can down-regulation of UDP-glucuronosyltransferases in the urinary bladder tissue impact the risk of chemical carcinogenesis? Int J Cancer 91(1): 141-143.

Guillemette C (2003) Pharmacogenomics of human UDP-glucuronosyltransferase enzymes. Pharmacogenomics J 3(3): 136-158.

Higdon JV, Frei B (2006) Coffee and health: a review of recent human research. Crit Rev Food Sci Nutr 46(2): 101-123.

Iida K, Mimura J, Itoh K, Ohyama C, Fujii-Kuriyama Y, Shimazui T, Akaza H, Yamamoto M (2010) Suppression of AhR signaling pathway is associated with the down-regulation of UDP-glucuronosyltransferases during BBNinduced urinary bladder carcinogenesis in mice. J Biochem 147(3): 353-360.

Iyanagi T (2007) Molecular mechanism of phase I and phase II drug-metabolizing enzymes: implications for detoxification. Int Rev Cytol 260: 35-112.

Jiang X, Castelao JE, Groshen S, Cortessis VK, Ross RK, Conti DV, Gago-Dominguez M (2007) Alcohol consumption and risk of bladder cancer in Los Angeles County. Int J Cancer 121(4): 839-845.
Jiang X, Castelao JE, Groshen S, Cortessis VK, Shibata DK, Conti DV, GagoDominguez M (2008) Water intake and bladder cancer risk in Los Angeles County. Int J Cancer 123(7): 1649-1656.

King CD, Rios GR, Green MD, Tephly TR (2000) UDP-glucuronosyltransferases. Curr Drug Metab 1(2): 143-161.

Kuo PL, Hsu YL (2008) The grape and wine constituent piceatannol inhibits proliferation of human bladder cancer cells via blocking cell cycle progression and inducing Fas/membrane bound Fas ligand-mediated apoptotic pathway. Mol Nutr Food Res 52(4): 408-418.

Kurahashi N, Inoue M, Iwasaki M, Sasazuki S, Tsugane S. Japan Public Health Center Study G (2009) Coffee, green tea, and caffeine consumption and subsequent risk of bladder cancer in relation to smoking status: a prospective study in Japan. Cancer Sci 100(2): 284-291.

Lampe JW (2007) Diet, genetic polymorphisms, detoxification, and health risks. Altern Ther Health Med 13(2): S108-S111.

Lin GF, Guo WC, Chen JG, Qin YQ, Golka K, Xiang CQ, Ma QW, Lu DR, Shen JH (2005) An association of UDP-glucuronosyltransferase 2B7 C802T (His268Tyr) polymorphism with bladder cancer in benzidineexposed workers in China. Toxicol Sci 85(1): 502-506.

Lin J, Wang J, Greisinger AJ, Grossman HB, Forman MR, Dinney CP, Hawk ET, Wu X (2010) Energy balance, the PI3K-AKT-mTOR pathway genes, and the risk of bladder cancer. Cancer Prev Res 3(4): 505-517.

Mackenzie PI, Gregory PA, Lewinsky RH, Yasmin SN, Height T, McKinnon RA, Gardner-Stephen DA (2005) Polymorphic variations in the expression of the chemical detoxifying UDP glucuronosyltransferases. Toxicol Appl Pharmacol 207(2 Suppl): 77-83.

Michaud DS, Kogevinas M, Cantor KP, Villanueva CM, Garcia-Closas M, Rothman N, Malats N, Real FX, Serra C, Garcia-Closas R, Tardon A, Carrato A, Dosemeci M, Silverman DT (2007) Total fluid and water consumption and the joint effect of exposure to disinfection by-products on risk of bladder cancer. Environ Health Perspect 115(11): 1569-1572.

Michaud DS, Spiegelman D, Clinton SK, Rimm EB, Curhan GC, Willett WC, Giovannucci EL (1999) Fluid intake and the risk of bladder cancer in men. N Engl J Med 340(18): 1390-1397.

Mueller NT, Odegaard A, Anderson K, Yuan JM, Gross M, Koh WP, Pereira MA (2010) Soft drink and juice consumption and risk of pancreatic cancer: the Singapore Chinese Health Study. Cancer Epidemiol Biomarkers Prev 19(2): 447-455.

Nkondjock A (2009) Coffee consumption and the risk of cancer: an overview. Cancer Lett 277(2): 121-125.

Odegaard AO, Koh WP, Arakawa K, Yu MC, Pereira MA (2010) Soft drink and juice consumption and risk of physician-diagnosed incident type 2 diabetes: the Singapore Chinese Health Study. Am J Epidemiol 171(6): 701-708.

Pelucchi C, Bosetti C, Negri E, Malvezzi M, La Vecchia C (2006) Mechanisms of disease: The epidemiology of bladder cancer. Nat Clin Pract Urol 3(6): 327-340.

Pelucchi C, La Vecchia C (2009) Alcohol, coffee, and bladder cancer risk: a review of epidemiological studies. Eur J Cancer Prev 18(1): 62-68.

Pelucchi C, Tavani A, La Vecchia C (2008) Coffee and alcohol consumption and bladder cancer. Scand J Urol Nephrol Suppl 42(218): 37-44.

Ros MM, Bas Bueno-de-Mesquita HB, Buchner FL, Aben KK, Kampman E, Egevad L, Overvad K, Tjonneland A, Roswall N, Clavel-Chapelon F, Kaaks $\mathrm{R}$, Chang-Claude J, Boeing H, Weikert S, Trichopoulou A, Orfanos P, Stasinopulou G, Saieva C, Krogh V, Vineis P, Tumino R, Mattiello A, Peeters PH, van Duijnhoven FJ, Lund E, Gram IT, Chirlaque MD, Barricarte A, Rodriguez L, Molina E, Gonzalez C, Dorronsoro M, Manjer J, Ehrnstrom R, Ljungberg B, Allen NE, Roddam AW, Khaw KT, Wareham N, Boffetta P, Slimani N, Michaud DS, Kiemeney LA, Riboli E (2011) Fluid intake and the risk of urothelial cell carcinomas in the European Prospective Investigation into Cancer and Nutrition (EPIC). Int J Cancer 128(11): 2695-2708.

Rothman N, Garcia-Closas M, Chatterjee N, Malats N, Wu X, Figueroa JD, Real FX, Van Den Berg D, Matullo G, Baris D, Thun M, Kiemeney LA, Vineis P, De Vivo I, Albanes D, Purdue MP, Rafnar T, Hildebrandt MA, Kiltie AE, Cussenot O, Golka K, Kumar R, Taylor JA, Mayordomo JI, Jacobs KB, Kogevinas M, Hutchinson A, Wang Z, Fu YP, ProkuninaOlsson L, Burdett L, Yeager M, Wheeler W, Tardon A, Serra C, Carrato A, Garcia-Closas R, Lloreta J, Johnson A, Schwenn M, Karagas MR, Schned A, Andriole Jr. G, Grubb 3rd R, Black A, Jacobs EJ, Diver WR, Gapstur SM, Weinstein SJ, Virtamo J, Cortessis VK, Gago-Dominguez M, Pike MC, Stern MC, Yuan JM, Hunter DJ, McGrath M, Dinney CP, Czerniak B, Chen M, Yang H, Vermeulen SH, Aben KK, Witjes JA, Makkinje RR, Sulem P, Besenbacher S, Stefansson K, Riboli E, Brennan P, Panico S, 
Navarro C, Allen NE, Bueno-de-Mesquita HB, Trichopoulos D, Caporaso N, Landi MT, Canzian F, Ljungberg B, Tjonneland A, Clavel-Chapelon F, Bishop DT, Teo MT, Knowles MA, Guarrera S, Polidoro S, Ricceri F, Sacerdote C, Allione A, Cancel-Tassin G, Selinski S, Hengstler JG, Dietrich H, Fletcher T, Rudnai P, Gurzau E, Koppova K, Bolick SC, Godfrey A, Xu Z, Sanz-Velez JI, D García-Prats M, Sanchez M, Valdivia G, Porru S, Benhamou S, Hoover RN, Fraumeni Jr. JF, Silverman DT, Chanock SJ (2010) A multi-stage genome-wide association study of bladder cancer identifies multiple susceptibility loci. Nat Genet 42(11): 978-984.

Siegel R, Ward E, Brawley O, Jemal A (2011) Cancer statistics, 2011: the impact of eliminating socioeconomic and racial disparities on premature cancer deaths. CA Cancer J Clin 61(4): 212-236.

Vena JE, Graham S, Freudenheim J, Marshall J, Zielezny M, Swanson M, Sufrin G (1993) Drinking water, fluid intake, and bladder cancer in western New York. Arch Environ Health 48(3): 191-198.

Villanueva CM, Cantor KP, Cordier S, Jaakkola JJ, King WD, Lynch CF, Porru S, Kogevinas M (2004) Disinfection byproducts and bladder cancer: a pooled analysis. Epidemiology 15(3): 357-367.

Villanueva CM, Cantor KP, King WD, Jaakkola JJ, Cordier S, Lynch CF, Porru S, Kogevinas M (2006) Total and specific fluid consumption as determinants of bladder cancer risk. Int J Cancer 118(8): 2040-2047.

Villanueva CM, Silverman DT, Murta-Nascimento C, Malats N, Garcia-Closas M, Castro F, Tardon A, Garcia-Closas R, Serra C, Carrato A, Rothman N,
Real FX, Dosemeci M, Kogevinas M (2009) Coffee consumption, genetic susceptibility and bladder cancer risk. Cancer Causes Control 20(1): 121-127.

Wu X, Lin J, Grossman HB, Huang M, Gu J, Etzel CJ, Amos CI, Dinney CP, Spitz MR (2007) Projecting individualized probabilities of developing bladder cancer in white individuals. J Clin Oncol 25(31): 4974-4981.

Wu X, Ros MM, Gu J, Kiemeney L (2008) Epidemiology and genetic susceptibility to bladder cancer. BJU Int 102(9 Pt B): 1207-1215.

Yang CS, Wang X, Lu G, Picinich SC (2009) Cancer prevention by tea: animal studies, molecular mechanisms and human relevance. Nat Rev Cancer 9(6): 429-439.

Zeegers MP, Dorant E, Goldbohm RA, van den Brandt PA (2001) Are coffee, tea, and total fluid consumption associated with bladder cancer risk? Results from the Netherlands Cohort Study. Cancer Causes Control 12(3): 231-238.

This work is published under the standard license to publish agreement. After 12 months the work will become freely available and the license terms will switch to a Creative Commons AttributionNonCommercial-Share Alike 3.0 Unported License.

Supplementary Information accompanies this paper on British Journal of Cancer website (http://www.nature.com/bjc) 